\begin{tabular}{|l|c|c|c|c|}
\hline $\begin{array}{l}\text { Cuadernos de Investigación Geográfica } \\
\text { Geographical Research Letters }\end{array}$ & 2020 & N $^{\circ} 46(2)$ & pp. 563-580 & eISSN 1697-9540 \\
\hline
\end{tabular}

\title{
FOG HARVESTING POTENTIAL FOR DOMESTIC RURAL USE AND IRRIGATION IN SAN CRISTOBAL ISLAND, GALAPAGOS, ECUADOR
}

\section{P. ECHEVERRÍA ${ }^{1}$, CH. DOMÍNGUEZ ${ }^{2 *}$, M. VILLACÍS ${ }^{1}$, S. VIOLETTE ${ }^{3,4}$}

\author{
${ }^{1}$ Facultad de Ingeniería Civil y Ambiental, Escuela Politécnica Nacional, Quito, Ecuador. \\ ${ }^{2}$ Carrera de Ingeniería Civil, Campus Sur, Universidad Politécnica Salesiana, Quito, Ecuador \\ ${ }^{3}$ UMR.8538 - Laboratoire de Géologie, ENS-PSL Research University, 24 rue Lhomond, Paris, France. \\ ${ }^{4}$ Sorbonne Université, 4, place Jussieu, 75005 Paris, France.
}

\begin{abstract}
The Galapagos Archipelago is a semiarid zone scarce of superficial water resources. Due to its geographic location and the presence of oceanic currents, these islands are covered by fog during seven months along the year which could represent a potential source of water supply. In this study, the feasibility of fog collection for domestic rural use and irrigation was investigated using two Standard Fog Collectors (SFC) of 50\% and 35\% shade coefficient of $1 \mathrm{~m}^{2}$ and a cylindrical fog net (CFN) of $0.15 \mathrm{~m}^{2}$ at $600 \mathrm{~m}$ of elevation in the windward side of San Cristobal Island (Galapagos). The methodology applied consists in the quantification of the monthly and annual water balance at different altitudes in an average and dry years, using the orographic gradients of rainfall, evapotranspiration and cloud water interception. The latter was used to estimate the fog water availability to satisfy any water deficit. Fog water interception was estimated using a geometric model and the use of different climatic variables. On the other hand, water demand in the rural zone for domestic consumption and livestock was estimated with the quota method, and the water demand for agriculture was estimated through the water balance. Results show that the amount of fog captured reaches 7.9, 5.9 and $3.4 \mathrm{~mm} / \mathrm{d}$ with 50-SFC, 35-SFC and CFN, respectively. Comparing these results with other locations in the world, fog water collection in Galapagos is above the average. A fog gauge system of 50-SFC was designed at different elevations to cover the $25 \%$ and $15 \%$ of the water deficit in the average and dry year, respectively.
\end{abstract}

\section{Captura de niebla para uso doméstico rural y riego en la Isla San Cristóbal, Galápagos, Ecuador}

RESUMEN. El archipiélago de Galápagos es una zona semiárida que carece de fuentes de agua superficiales. Debido a su posición geográfica y a la presencia de corrientes oceánicas, estas islas están cubiertas de neblina durante siete meses al año, lo que puede representar una fuente potencial de suministro de agua para 
la población. En este estudio, se investigó la factibilidad de la captura de niebla para uso rural y riego mediante el uso de dos colectores estándar de niebla (SFC) de $50 \%$ y $35 \%$ de coeficiente de sombra de $1 \mathrm{~m}^{2}$ y una red cilíndrica (CFN) de $0,15 m^{2}$ a 600 m de elevación en el barlovento de la isla San Cristóbal (Galápagos). La metodología aplicada consiste en la cuantificación del balance hidrológico mensual y anual a diferentes altitudes en un año promedio y en un año seco, utilizado los gradientes orográficos de precipitación, evapotranspiración e intercepción de niebla. Este último fue usado para estimar la disponibilidad de agua de niebla para satisfacer cualquier déficit hídrico. La intercepción de niebla se estimó por medio de un modelo geométrico y el uso de diferentes variables climáticas. Por otra parte, la demanda de agua en la zona rural para consumo doméstico y ganadería se estimó por el método de cuotas, mientras que la demanda de agua para agricultura se calculó a través del balance hidrológico. Los resultados muestran que la cantidad de niebla capturada alcanza los 7,9, 5,9 y 3,4 mm/d con el colector 50-SFC, 35-SFC y CFN, respectivamente. Comparando estos resultados con otros lugares alrededor del mundo, se evidenció que la captura de niebla en Galápagos supera el promedio. Un sistema de colectores de 50-SFC se diseñó a diferentes elevaciones para cubrir el $25 \%$ y el $15 \%$ del déficit de agua en el año promedio y el año seco, respectivamente.

Keywords: Fog water interception, fog, water balance, water deficit, Galapagos.

Palabras clave: intercepción de agua de neblina, niebla, balance hidrológico, déficit de agua, Galápagos.

*Corresponding author: Christian Domínguez, Carrera de Ingeniería Civil, Campus Sur, Universidad Politécnica Salesiana, Quito, Ecuador. E-Mail address: cdominguez@ups. edu.ec.

\section{Introduction}

The Galapagos Archipelago is a semi-arid zone where most of their islands suffer from the lack of superficial water resources, which limits the development of productive activities, and therefore, it affects the life quality of their inhabitants. Water supply in most of the main islands is obtained from the exploitation of the basal aquifer, which is highly exposed to sea water intrusion and contamination (Violette et al., 2014). The increase of population and the development of economic activities related to the tourism industry put pressure over a scarce and fragile resource, such as freshwater. Therefore, it is necessary to find alternatives to enhance water supply in Galapagos, such as fog harvesting. Indeed, these islands are covered by a semi-permanent fog layer in the windward side (above $250 \mathrm{~m}$ a.s.1.), from June to December. Such circumstances could be resourceful to consider fog as a potential source for water supply. 
At the moment, there are several projects of fog collection around the world (Chile, Ecuador, South Africa, Namibia, Oman, Saudi Arabia, Spain). According to the literature, the average yield of different fog collectors ranges between 2 and $101 / \mathrm{m}^{2}$ day (Abdul et al., 2010; Batisha, 2015; Cereceda et al., 1992; Estrela et al., 2008; Fessehaye et al., 2014; Klemm et al., 2012; Ritter et al., 2015). However, values up to $3001 / \mathrm{m}^{2}$ day have been registered with an omnidirectional Standard Fog Collector (SFC) in one occasion in Oman (Schemenauer and Cereceda, 1994a).

In this context, the feasibility of water fog collection and its quantification for domestic use and irrigation has been investigated in this study. An experimental site was equipped with a meteorological station and three different fog net gauges. This research was conducted during a study period of 48 days, in San Cristobal Island.

\section{Study area}

\subsection{Climate}

Galapagos Islands are located at $1000 \mathrm{~km}$ west from the mainland. The climate is atypical according to the Galapagos geographical position. The climate is influenced by the presence of the Inter-tropical Convergence Zone (ITCZ), which is a warm band of deep convection (Sachs et al., 2009) where the trade winds from the northeast and southeast converge. The ITCZ movement from north to south results in variations of the predominant trade winds from the southeast (SE) and the ascendant cold ocean currents (Equatorial and Humboldt) that converge in the Archipelago (Trueman and d'Ozouville, 2010; Violette et al., 2014), determining the seasonality of Galapagos. According to Alpert (1946), when the ITCZ migrates towards south, the trade winds are reduced, as well as the cold currents, and then the warm currents arrive from the north, giving these islands tropical conditions (Trueman and d'Ozouville, 2010).

The mixed effects of these events result in two seasons along the year, the hot "invierno" season, from January to May, and the cold "garua" season from June to December. During the "garua" season, an inversion layer is formed where the air masses cooled by the ocean surface are trapped below the hot air masses, causing condensation (Trueman and d'Ozouville, 2010). This is relevant in the windward side, because the trade winds push these air masses against the island profile (Fig. 1). Condensation occurs above $250 \mathrm{~m}$ a.s.l., forming stratus clouds, and producing orographic rainfalls accompanied by fog (Trueman and d'Ozouville, 2010). The presence of fog can be observed semi-permanently during this season. In the "invierno" season, the temperature of the air and the ocean surface is higher, resulting in convective rainfall events with high intensity and spatial variability (Trueman and d'Ozouville, 2010). According to the historical records from the climatic station (6 $\mathrm{m}$ a.s.1.) operated by the Charles Darwin Foundation, the average temperature is $24^{\circ} \mathrm{C}$ and the median annual rainfall is $287 \mathrm{~mm}$ in Santa Cruz Island between 1965 and 2015 (Domínguez, 2016). 


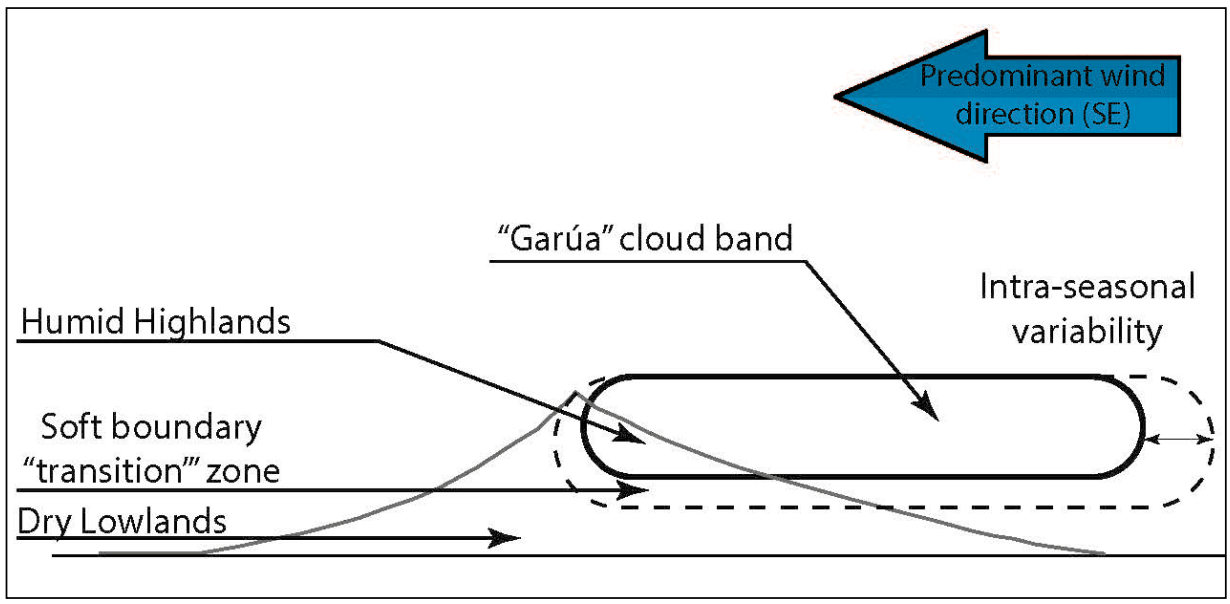

Figure 1. Climatic zonation in the "garua" season (Trueman and d'Ozouville, 2010).

\subsection{Geography, demography and study site}

San Cristobal is located to the east of the Galápagos Archipelago. This is the only island with permanent superficial water resources located on the windward side. Several sources, fed from perched aquifers, form ravines that flow at mid-elevation, whereas some re-infiltrate to the ground, others discharge on the sea (Domínguez, 2016). Their inhabitants are entirely dependent of these sources.

The population in San Cristobal reaches 7475 inhabitants, of which 803 of them live in the rural zone (INEC, 2010). The water supply for total domestic consumption in the island is $231 \mathrm{~s} \mathrm{~s}^{-1}$, equivalent to 266 liters per inhabitant per day (1/inh.day). The suggested water supply in the rural zone is $2001 /$ inh.day according to technical studies (CISPDR, 2015). Even though, the demand of water for consumption is regularly satisfied (contrary to the case of the other inhabited islands), water supply for irrigation is very limited. According to the CISPDR (2015), water needed for irrigation reaches $14.31 \mathrm{~s}^{-1}$.

This research was developed in the agricultural zone, that extends from the midlands to the summit, on the windward side of the island. An experimental site was set up at $600 \mathrm{~m}$ a.s.1. (Fig. 2). This site was chosen to ensure the presence of fog during the study period and the elevation is similar to several farms located on the island. In this zone, vegetation is principally composed by: (i) ferns and endemic forest of Miconia Robinsoniana, characterized as low elevation cloud forest according to Pryet et al. (2012); and (ii) sown fields of pasture (Domínguez, 2016). Records from a weather station at $300 \mathrm{~m}$ a.s.l. located in the humid zone of the island were used as well. In this zone, the endemic vegetation has been replaced by pasture and secondary forest composed by introduced species (Pryet et al., 2012). 


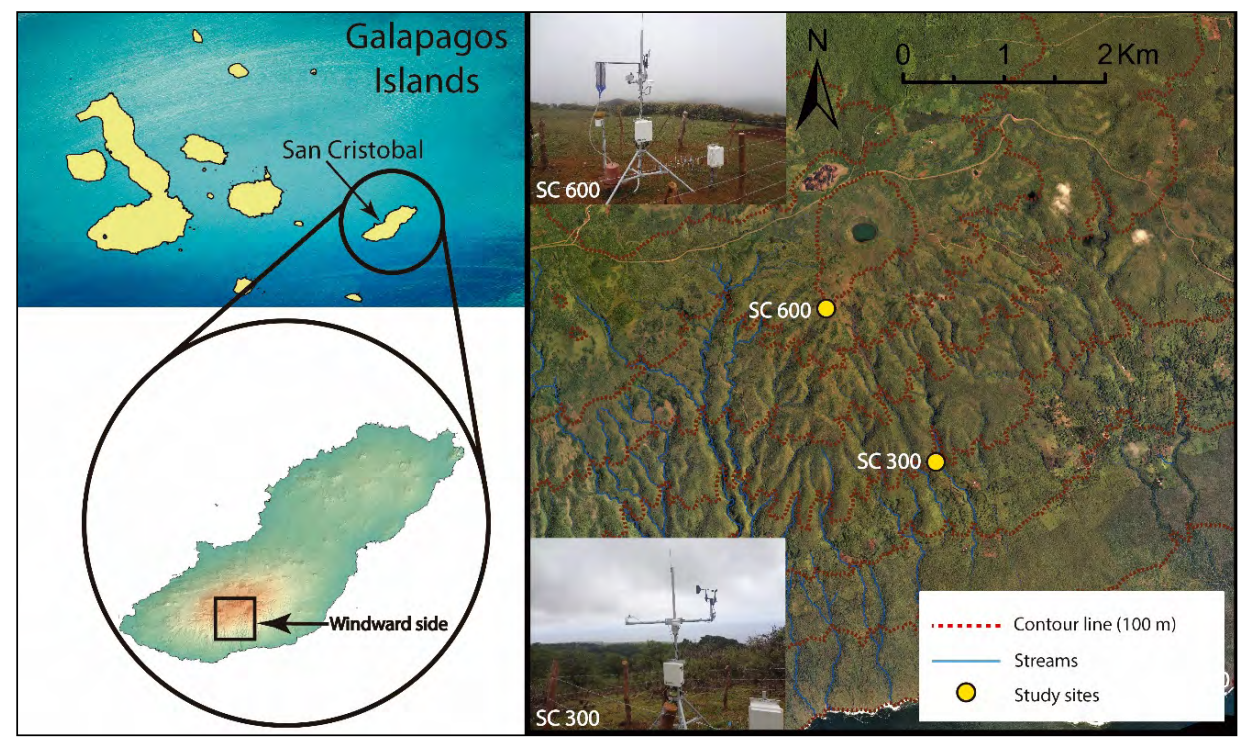

Figure 2. Weather stations in the windward side of San Cristobal Island at $600 \mathrm{~m}$ a.s.l., and $300 \mathrm{~m}$ a.s.l. (Imagen taken from IGM, 2014).

\section{Methods}

\subsection{Climatic variables monitoring}

The climatic variables were monitored using a meteorological station at $600 \mathrm{~m}$ a.s.l. (Fig. 3). Data was recorded with a Campbell CR1000 datalogger at 15-minutes time steps. Solar radiation, relative humidity and air temperature were measured $2 \mathrm{~m}$ above the ground, with a silicone pyranometer Kipp and Zonen SPLite and a Campbell CS215 $T \& R H$ sensor, respectively. Wind velocity and wind direction were measured $2 \mathrm{~m}$ above the ground with a Young Wind Sentry Kit anemometer; and rainfall was recorded with a Texas TE525MM tipping bucket rain gauge at $1.5 \mathrm{~m}$ above the ground. Finally, fog interception was measured with a cylindrical fog net (CFN) with $12 \mathrm{~cm}$ in diameter and $40 \mathrm{~cm}$ tall, covered by a $1 \mathrm{~mm}$ plastic mesh. CFN was connected to a rain gauge using a plastic funnel $2 \mathrm{~m}$ above the ground. In addition, we used two standard fog collectors $(1 \times 1 \mathrm{~m})$ made of polyethylene mesh with 50\% (50-SFC) and 35\% (35-SFC) shade coefficient. The mesh is supported with a PVC structure located $2 \mathrm{~m}$ above the soil surface. In order to obtain continuous measurements of fog interception by the gauges, the CFN and 50-SFC were connected to an individual Précis Mécanique R307AO tipping bucket rain gauge and the 35-SFC was connected to a Campbell ARG100 tipping bucket rain gauge. A similar monitoring was performed in the weather station at $300 \mathrm{~m}$ a.s.l. However, fog was not recorded because the cloud base was usually above this level and thus fog is expected to be negligible at this altitude. 


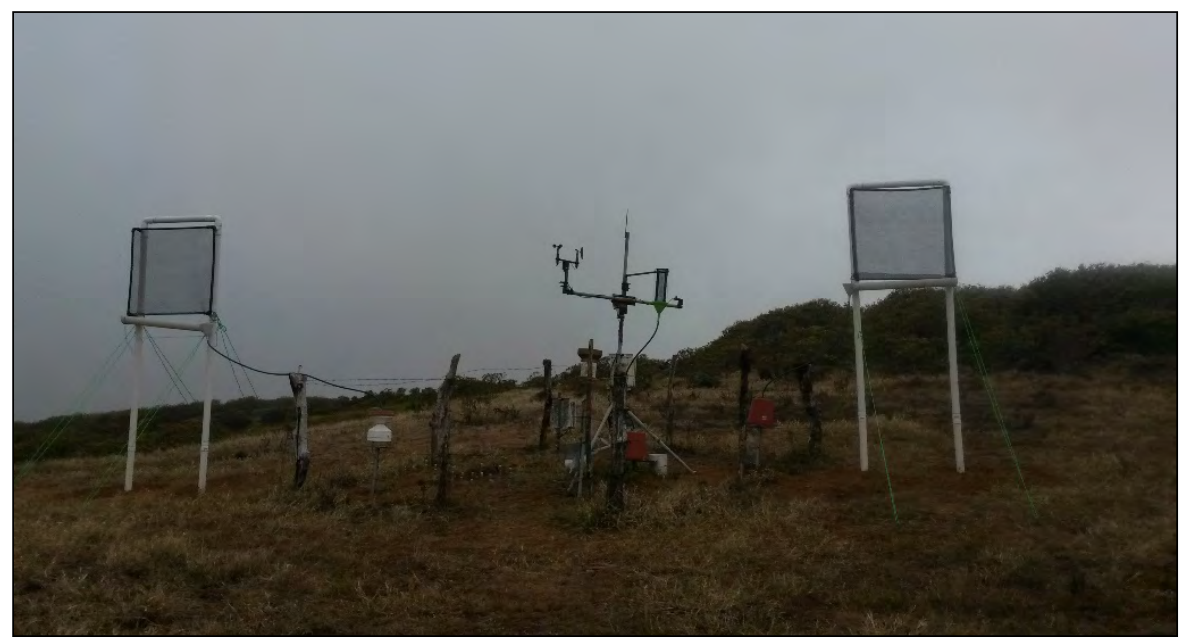

Figure 3. Meteorological station at $600 \mathrm{~m}$ a.s.l. in San Cristobal Island. a) 35-SFC, b) CFN, and c) $50-S F C$.

Records obtained by the two weather stations correspond to a period of three years (2013-2016). However, the two standard fog collectors were installed in June 2016, and their records correspond to a 48-days period. We used a correction factor to estimate the amount of water captured by the standard collectors during the average year.

\subsection{Model and data analysis}

Total precipitation recorded by the three fog gauges is composed of rainfall and fog. We used a geometric model based on rainfall inclination to separate both components. Rainfall inclination angle is determined for each time step from the rainfall intensity, drop diameter, drop fall velocity and wind speed, according to procedure described by Holwerda et al. (2006). In this way, the amount of rainfall caught by the fog collectors is estimated from the rainfall inclination angle, the collector surface and the actual rainfall.

Drop diameter $(D)(\mathrm{mm})$ is obtained from rainfall intensity $(R)(\mathrm{mm} / \mathrm{h})($ Holwerda et al., 2006; Laws and Parsons, 1943):

$$
\mathrm{D}=2.23(0.03937 \mathrm{R})^{0.102}
$$

Drop fall velocity $(V)(\mathrm{m} / \mathrm{s})$ is obtained from the drop diameter (Gunn and Kinzer, 1949; Holwerda et al., 2006):

$$
V=3.378 \ln (D)+4.213
$$

Precipitation falls with an inclination angle as a consequence of the wind influence, this angle is calculated as it follows (Domínguez et al., 2017; Herwitz and Slye, 1995; Holwerda et al., 2006): 


$$
\tan (b)=\frac{U}{V}
$$

where $b$ is the rainfall inclination angle and $U$ is the wind speed at each time step $(\mathrm{m} / \mathrm{s})$.

Once the angle is obtained, it is possible to calculate the actual rainfall $\left(R F_{a}\right)$ at every time step from the total precipitation recorded in the rain gauge of the fog collectors $\left(R F_{V}\right)$ (Domínguez et al., 2017):

$$
R F_{a} \frac{R F_{v}}{\cos (b)}
$$

The volume of net rainfall in the collector $(V F)$ is determined by actual rainfalland the collector surface projection $\left(S_{e}\right)$ perpendicular to the direction of $R F_{a}$ (Domínguez et al., 2017):

$$
V F_{r}=R F_{a} * S_{e}
$$

Fog (CWI) (mm) is obtained from the difference between the total water volume measured by the gauge $\left(V F_{T}\right)$ and the volume of net rainfall divided by the collection surface $\left(A_{c}\right)$ :

$$
C W I=\frac{\left(V F_{r}-V F_{r}\right)}{\mathrm{A}_{c}}
$$

The model was applied continuously at each time step during the 48-days period, from June to July (2016). In order to determine the influence of meteorological variables on fog collection, a statistical analysis was carried out with different variables, such as air temperature, solar radiation, wind speed and direction, relative humidity and rainfall. This analysis consisted in the determination of the influence of each variance variable to the variance of fog estimates through a quantitative analysis proposed by Sicart et al. (2008):

$$
r\left(x_{i,}, F o g\right)=\sum_{i} \frac{\sigma_{x i}}{\sigma_{F o g}} r\left(x_{i}\right)
$$

where $\sigma_{x i}$ is the standard deviation of the climatic variable, $\sigma_{F o g}$ is the standard deviation of fog and $r\left(x_{i}\right)$ is regression coefficient between the climatic variable and fog.

\subsection{Estimation of water supply and demand}

In San Cristobal Island, there is water demand for productive activities such as agriculture, livestock, and domestic consumption, in which agriculture is the most demanding one. The water demand for domestic consumption and livestock was calculated through the quota method, as it is shown in equation (8) and (9), respectively. 


$$
\begin{aligned}
& W_{i} \frac{P_{r} * Q_{r}}{\mathrm{n}_{r}} \\
& W_{g} \frac{P_{G} * Q_{G}+P_{g} * Q_{g}}{\mathrm{n}_{c}}
\end{aligned}
$$

where $W_{i}$ is the demand of water for domestic consumption, $P_{r}$ is the number of inhabitants in the rural zone (inh), $Q_{r}$ is the quota for domestic water consumption in the rural zone (1/inh.day) and $n_{r}$ is the water use coefficient in the rural zone. In the case of livestock, $W_{g}$ is the demand of water, $P_{G}$ and $P_{g}$ is the number of the bigger cattle and the smaller cattle, respectively. $Q_{G}$ and $Q_{g}$ is the quota for water consumption of the bigger and smaller cattle, respectively (l/catt.day), and $n_{c}$ is the water use coefficient in the rural zone.

The estimation of the agriculture water demand was obtained for each farm in the rural zone of the island in accordance to the water availability calculated from the hydrological balance between precipitation and potential evapotranspiration:

$$
Q_{s}=\mathrm{P}-\mathrm{ETP} * k_{c}
$$

where $Q_{s}$ is the water availability, $P$ corresponds to the precipitation ( $\left.\mathrm{mm}\right), E T P$ is the potential evapotranspiration of the reference crop (mm) (FAO, 2006), and $k_{c}$ is the crop coefficient. In order to simplify the estimation, we established $100 \mathrm{~m}$ elevation ranges. Every farm was assigned to one of these ranges depending of their elevation. Then, the water deficit (when $Q_{s}$ is negative) for agriculture was determined at each range. Individual orographic gradients were calculated to obtain precipitation and potential evapotranspiration at each elevation range using:

$$
\left\{\begin{array}{l}
P_{z}=b_{1}+a_{1} \mathrm{z} \\
\operatorname{ETP}_{\mathrm{z}}=\left(b_{2}+a_{2} z\right) \mathrm{k}_{\mathrm{c}}
\end{array}\right.
$$

Where $P_{Z}$ and $E T P_{Z}$ are rainfall and crop evapotranspiration at an elevation z, respectively. $b_{1}, a_{1}, b_{2}$ and $a_{2}$ are regression parameters.

The crop coefficient refers to the effects of crop transpiration and the soil evaporation considering the crop features (FAO, 2006). This coefficient was estimated following the methodology proposed by FAO (2006) and was adjusted according to the conditions of relative humidity and wind speed prevailing in San Cristobal.

$$
k_{c}=K_{c i}+\left[0.04\left(u_{2}-2\right)-0.004\left(H R_{\min }-45\right)\right](\mathrm{h} / 3)^{0.3}
$$

where $K_{c i}$ is the value of $k_{c}$ obtained by FAO (2006), $u_{2}$ is the mean daily value of wind speed $2 \mathrm{~m}$ above grass for middle growth season $(\mathrm{m} / \mathrm{s})$, between $1 \mathrm{~m} / \mathrm{s} \leq u_{2} \leq 6 \mathrm{~m} / \mathrm{s}$. $H R_{\text {min }}$ is the mean value of relative humidity during middle growth season (\%), for $20 \% \leq H R_{\min }^{\min }$ 
$\leq 80 \%$ and $h$ is the mean hight of the plants during middle growth season (m) for $0.1 \mathrm{~m}$ $\mathrm{s} \leq h \leq 10 \mathrm{~m}$.

$H R_{\min }$ is calculated by:

$$
H R_{\min }=\frac{e^{o}\left(T_{\min }\right)}{e^{o}\left(T_{\max }\right)} 100
$$

Considering that in normal conditions minimum temperature $T_{\min }$ approximates dew temperature $T_{d}$, where maximum relative humidity $H R_{\max }$ is close to $100 \%$, then the vapor pressure deficit (difference between saturation vapor pressure and real vapor pressure) is $\left[\left(100-H R_{\min }\right) / 200\right] e^{o}\left(\mathrm{~T}_{\max }\right)$, where $e^{o}\left(T_{\max }\right)$ is the saturation vapor pressure at a maximum daily air temperature. Coffee is the main crop cultivated in the island, and it corresponds to $74 \%$ of the surface of permanent isolated crops, while many others have a less significant percentage. For this reason, the $26 \%$ of the other crops was analyzed with a crop coefficient of reference (FAO, 2006). As a result, crop coefficient for coffee is 0.93 , while crop coefficient for the agricultural zone of San Cristobal is 0.74 .

Water availability was estimated at each elevation range considering measurements from the average and dry years. Monthly and annual values were calculated. Once the water deficit was estimated, we proceeded to estimate fog interception. The fog orographic gradient is estimated similar to the ones of precipitation and evapotranspiration (equation 11), although considering that the cloud base is located at $300 \mathrm{~m}$ of elevation. Below this altitude fog interception is considered negligible.

$$
C W I_{z}=a_{3}(z-300)+b_{3} ; \text { if }>300
$$

where $C W I_{Z}$ is cloud water interception at an elevation $\mathrm{z}$ and $a_{3}$ and $b_{3}$ are regression parameters. In order to obtain the amount of fog interception with the standard collectors, we used a correction factor relating the cumulative amount of fog captured by a standard fog collector and the cylindrical fog net during the common monitoring period, then:

$$
C W I_{S F C}=C W I_{C F N} \cdot r
$$

where $r$ is the correction factor, $C W I_{S F C}$ is the cloud water interception with a standard fog collector at any month, and $C W I_{C F N}$ is the cloud water interception with the CFN in any month.

Finally, we estimated cloud water interception by different of gauges and compared to the water deficit obtained at different elevation ranges by month and year. Then, we estimated the collection surface required in $\mathrm{m}^{2}$ of the fog gauges for each elevation range to cover part of the water deficit. 


\section{Results}

\subsection{Climatic conditions}

During the study period, records from the weather station at $600 \mathrm{~m}$ of elevation show that average temperature was $18.2^{\circ} \mathrm{C}$, average wind speed was $2.5 \mathrm{~m} / \mathrm{s}$ and the most frequent wind direction was around $199^{\circ}$. Net precipitation reached $72 \mathrm{~mm}$ and average solar radiation was $211 \mathrm{~W} / \mathrm{m}^{2}$. On the other hand, at $300 \mathrm{~m}$ a.s.l., average temperature was $21.1^{\circ} \mathrm{C}$, average wind speed was $1.6 \mathrm{~m} / \mathrm{s}$, the most frequent wind direction was $203.3^{\circ}$, net precipitation reached $30 \mathrm{~mm}$ and average solar radiation was $208.3 \mathrm{~W} / \mathrm{m}^{2}$.

\subsection{Quantification of fog}

As a result of the application of the model during the study period, fog collected by 50-SFC, 35-SFC and CFN is 352, 284 and $165 \mathrm{~mm}$, respectively, equivalent to 7.9, 5.9 and $3.4 \mathrm{~mm}$ day $^{-1}$. Fog estimated at 50-SFC, 35-SFC and CFN represents 490\%, 394\% and $229 \%$ of total rainfall, respectively, which is a considerable amount in a water balance. Considering precipitation events alone (without non-precipitation periods), mean fog intensities reached $0.26,0.25$ and $0.08 \mathrm{~mm} / \mathrm{h}$ for $50-\mathrm{SFC}, 35-\mathrm{SFC}$ and $\mathrm{CFN}$, respectively.

High correlations were found between the three fog nets, both for water volume and fog, as it is shown in Table 1 and Table 2.

Table 1. Volume of water (fog and rainfall) recorded with the rain gauges connected to CFN, 50SFC and 35-SFC correlation.

\begin{tabular}{|l|c|c|c|}
\hline \multicolumn{1}{|c|}{ Volume } & CFN & 50-SFC & 35-SFC \\
\hline CFN & 1 & 0.90 & 0.81 \\
\hline $50-F N$ & & 1 & 0.94 \\
\hline $35-F N$ & & & 1 \\
\hline
\end{tabular}

Table 2. Volume of fog captured by the CFN, 50-SFC and 35-SFC collector correlation.

\begin{tabular}{|l|c|c|c|}
\hline \multicolumn{1}{|c|}{ Fog } & CFN & 50-SFC & 35-SFC \\
\hline CFN & 1 & 0.76 & 0.57 \\
\hline $50-F N$ & & 1 & 0.88 \\
\hline $35-F N$ & & & 1 \\
\hline
\end{tabular}

\subsection{Influence of climatic variables in fog collection}

All three devices capture more fog as wind speed increases. The amount of fog collected by CFN could be considered negligible up to $4 \mathrm{~m} \mathrm{~s}^{-1}$. Above this value, it becomes considerable. However, fog collected between 4 and $6 \mathrm{~m} \mathrm{~s}^{-1}$ does not appear to increase markedly according to wind speed such as the case of the other collectors. In the case of SFC, fog is negligible with velocities below $4 \mathrm{~m} \mathrm{~s}^{-1}$, above this value fog increases considerably according to the wind speed (Fig. 4). 


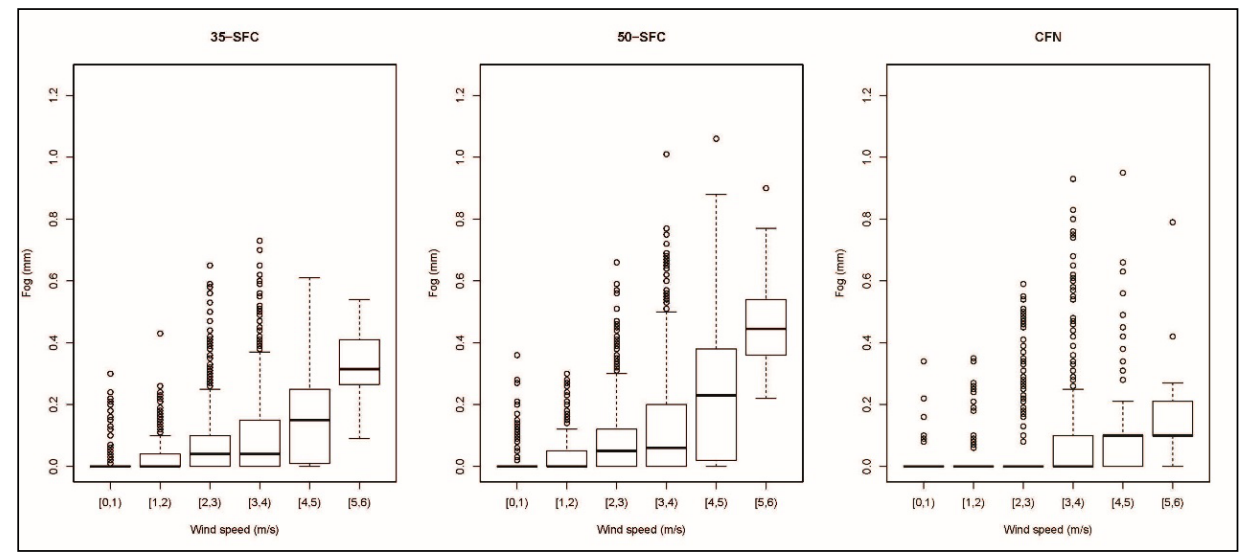

Figure 4. Statistics of fog interception in each collector classified by winds speed intervals during the study period (June-July, 2016).

The statistical analysis shows that wind speed is the most influential variable on the amount of fog collected by the three collectors. Rainfall contributes to fog collection in $59 \%, 16 \%$ and $3 \%$ with CFN, 50-SFC and 35-SFC, respectively. Wind speed influence is $31 \%, 53 \%$ and $51 \%$ with CFN, 50-SFC and 35-SFC, respectively. Influence of solar radiation on fog collection is $-25 \%,-52 \%$ and $-55 \%$ in $\mathrm{CFN}, 50-\mathrm{SFC}$ and $35-\mathrm{SFC}$, respectively. The influence of other climatic variables on fog is negligible.

\subsection{Analysis of water offer and demand}

According to the hydrological balance, we found that water deficit is higher at lower elevations and lower at the highlands. It was expected considering the orographic gradients and the absence of fog at lower altitudes. The months with higher deficit at these altitudes correspond to the period between December and June on both, the average and dry year.

In the average year, only March has a water deficit at all elevations, whereas the deficit on the dry year extends from March to May at all elevations. Yet, March is the driest month of the year in terms of precipitation in both scenarios.

According to the data from the weather station at $600 \mathrm{~m}$ a.s.l., cloud water interception was present during seven months throughout the year, and the months with higher fog collection potential correspond to August, September and October, in both average and dry years.

The amount of water needed for agricultural purposes corresponds to the $99.8 \%$ of the total demand in San Cristobal. Therefore, this is the only component taken into consideration. Considering all farms needs, the total amount of water deficit for agricultural purposes in San Cristobal was 287,443 and $328,075 \mathrm{~m}^{3}$, in the average and dry year, respectively. Considering that $50-\mathrm{SFC}$ is the most efficient collector, the total amount of fog collected at an average altitude in the island throughout the average year with $1 \mathrm{~m}^{2}$ of the $50-\mathrm{SFC}$ could reach $22.6 \mathrm{~m}^{3}$. In order to cover the 25 and $15 \%$ of 
the water deficit, in the average and dry year, respectively, we estimated the collection surface required in $\mathrm{m}^{2}$ at each range of elevation. On both scenarios, the greater collection surface is needed in the midlands, where the agricultural zone begins. In the average year, 22 standard fog collectors of $50 \%$ shade coefficient with a total collection surface of $850 \mathrm{~m}^{2}$ are required to cover the $25 \%$ of the water deficit $\left(2787 \mathrm{~m}^{3}\right)$. In the case of the dry year, the total collection surface required is $1175 \mathrm{~m}^{2}$, which means it is necessary 30 standard fog collectors of $50 \%$ shade coefficient to satisfy the $15 \%$ of the water deficit $\left(6455 \mathrm{~m}^{3}\right)$. These results are shown in Table 3 and Table 4.

Table 3. Water deficit covered in an average year with a 50-SFC system. For every elevation range, the table shows the amount of fog collected, the fog collection surface needed to cover the $25 \%$ of its water deficit, the total number of fog collectors needed and the collection surface required of a single standard fog collector.

\begin{tabular}{|l|c|c|c|c|c|c|c|}
\hline $\begin{array}{c}\text { Elevation } \\
(\mathbf{m})\end{array}$ & $\begin{array}{c}\text { Average farm } \\
\text { surface }\left(\mathbf{m}^{2}\right)\end{array}$ & $\begin{array}{c}\text { Water deficit } \\
\left(\mathbf{m}^{3}\right)\end{array}$ & $\begin{array}{c}\text { Cloud water } \\
\text { interception }\left(\mathbf{m}^{3}\right)\end{array}$ & $\begin{array}{c}\text { Fog colleting } \\
\text { surface }\left(\mathbf{m}^{2}\right)\end{array}$ & $\begin{array}{c}\text { Deficit } \\
\text { covered }(\mathbf{\%})\end{array}$ & $\begin{array}{c}\text { Number of } \\
\text { 35-SFC }\end{array}$ & $\begin{array}{c}\text { SFC } \\
\text { surface }\end{array}$ \\
\hline $300-399$ & 65710.99 & 2787.12 & 1.22 & 850 & 25.16 & 22 & $10 \times 4$ \\
\hline $400-499$ & 180231.24 & 6543.88 & 4.12 & 590 & 25.18 & 15 & $10 \times 4$ \\
\hline $500-599$ & 247434.03 & 7295.22 & 6.78 & 400 & 25.16 & 10 & $10 \times 4$ \\
\hline $600-700$ & 399261.68 & 9916.88 & 9.32 & 395 & 25.13 & 10 & $10 \times 4$ \\
\hline$>700$ & 75710.25 & 1462.09 & 11.99 & 45 & 25.00 & 4 & $6 \times 2$ \\
\hline
\end{tabular}

Table 4. Water deficit covered in a dry year with a 50-SFC system. For every elevation range, the table shows the amount of fog collected, the fog collection surface needed to cover the $25 \%$ of its water deficit, the total number of fog collectors needed and the collection surface required of a single standard fog collector.

\begin{tabular}{|l|c|c|c|c|c|c|c|}
\hline $\begin{array}{c}\text { Elevation } \\
(\mathbf{m})\end{array}$ & $\begin{array}{c}\text { Average farm } \\
\text { surface }\left(\mathbf{m}^{2}\right)\end{array}$ & $\begin{array}{c}\text { Water deficit } \\
(\mathbf{m} 3)\end{array}$ & $\begin{array}{c}\text { Cloud water } \\
\text { interception } \\
(\mathbf{m} 3)\end{array}$ & $\begin{array}{c}\text { Fog colleting } \\
\text { Surface }\left(\mathbf{m}^{2}\right)\end{array}$ & $\begin{array}{c}\text { Deficit cov- } \\
\text { ered }(\mathbf{\%})\end{array}$ & $\begin{array}{c}\text { Number of } \\
\mathbf{3 5 - S F C}\end{array}$ & $\begin{array}{c}\text { SFC } \\
\text { surface }\end{array}$ \\
\hline $300-399$ & 65710.99 & 6454.99 & 1.22 & 1175 & 15.01 & 30 & $10 \times 4$ \\
\hline $400-499$ & 180231.24 & 15710.12 & 4.12 & 845 & 15.02 & 22 & $10 \times 4$ \\
\hline $500-599$ & 247434.03 & 19017.49 & 6.77 & 625 & 15.08 & 16 & $10 \times 4$ \\
\hline $600-700$ & 399261.68 & 27885.53 & 9.31 & 665 & 15.05 & 17 & $10 \times 4$ \\
\hline$>700$ & 75710.25 & 4655.88 & 11.98 & 86 & 15.00 & 8 & $6 \times 2$ \\
\hline
\end{tabular}

\section{Discussion}

\subsection{Influence of climatic variables}

Fog interception is considerable with the three collectors. Nevertheless, these collectors present different collection efficiencies. It is higher with 50-SFC, followed by 35-SFC and, finally CFN. The collection efficiency of a fog collector depends on its aerodynamic efficiency, its impaction efficiency and its draining efficiency (Regalado and Ritter, 2017; Rivera, 2011). The aerodynamic efficiency is the ability of the mesh to pass through the air flux with fog without disturbing it. The impaction efficiency refers to the 
ability of the mesh to trap the drops of water from fog passing through the mesh, and the draining efficiency refers to the water that reaches the gutter once it was captured by the mesh. Contrary to SFC, the cylindrical shape of the CFN promotes the lateral flux of air with fog, so instead of passing through the mesh, it goes around its surface, decreasing its ability to intercept fog. The SFC net arrangement promotes drainage in comparison with the plane cylindrical fog net (Frumau et al., 2011), where water can be retained by the adhesive forces between the liquid and the holes of the net, preventing the pass through the mesh and therefore reducing fog capture (Cereceda et al., 2014; Ritter et al., 2008; Schemenauer and Joe, 1989). Even though CFN impaction efficiency is improved by the small holes of the mesh and its high shade coefficient, fog interception is reduced because the drops captured by the mesh can block the air flux, decreasing its permeability, so not only this air flux is not able to pass through but it could carry the drops that were already impregnated in the mesh with it, preventing this fog water to reach the gutter. This situation could be worse due to the reduction of the draining efficiency, caused by the horizontal arrangement of the mesh fibers, with little space between them.

We found that wind speed is the most influential variable on fog collection, such results have been reported in other studies as well (Ritter et al., 2008; Schemenauer and Joe, 1989). Fog interception is more efficient at higher wind speed ranges (Schemenauer and Cereceda, 1994). In the case of San Cristobal, we found similar results on fog interception by the three collectors used (Fig. 4). This could be explained considering the two main processes involved in fog interception: deposition and impaction. The first takes place at low wind speed conditions and high fog water content, and the second, occurs on high wind speed conditions. However, it is known that fog water content is inversely proportional to wind speed, due to the increase of potential evaporation (Villegas et al., 2008). Thus, it is expected that the rise of fog interception with the increase of wind speed until a point where fog water content starts to reduce. Beyond this point (with the presence of higher wind speed), fog interception is expected to decrease. In the case of San Cristobal, given that the higher wind speed do not reduce fog interception, it appers that fog water content is relatively high, which highlights the fog harvesting potential of the island.

The influence of wind direction on fog interception is negligible in the three collectors, even in the SFC. This could be explained because wind direction during the fog periods remained nearly constant. This fact could be explained by the presence of the predominant trade winds from the southeast of the island (Domínguez, 2016). We also found low radiation during days of high fog interception. Indeed, the presence of fog reduces solar radiation, as it occurs in the leeward side of Hawaii, in Puerto Rico and in the Canary Islands (Eugster et al., 2006; Giambelluca and Nullet, 1991; Ritter et al., 2008). However, solar radiation was correlated with rainfall as well, and according to Brauman et al. (2010), rain clouds block even more solar radiation than fog. This means that low radiation could not explain entirely the presence of fog.

\subsection{Comparison of results with other studies and applicability}

In San Cristobal, $7.91 / \mathrm{m}^{2} \cdot$ day of fog was obtained with the most efficient fog net (SFC50); this value is comparable with other sites around the world. In Chile, 
Perú and Oman, average fog interception reached 3, 9 and $301 / \mathrm{m}^{2}$ day, respectively, during the fog season (Schemenauer and Cereceda, 1994b). Fog interception has been considerable in other places such as the west coast of South Africa, where values reach 0.4 and $1.31 / \mathrm{m}^{2}$ day in Brand se Baai and Kalkbaken se Kop (Olivier, 2002), respectively. In Kalkbaken se Kop, fog interception is higher than Brand se Baaj. It is attributed to its location at a higher elevation and its exposition to higher wind speeds as well, reaching $5.2 \mathrm{~m} \mathrm{~s}^{-1}$, while in Brand se Baai wind speed reaches $4.3 \mathrm{~m} \mathrm{~s}^{-1}$ (Olivier, 2002). In Cape Columbine, the average water collection is $0.71 / \mathrm{m}^{2}$ day, and regarding to fog, the average is $2.41 / \mathrm{m}^{2}$ day (Olivier, 2002). In the Canary Islands fog collection ranges between 0.2 and $0.51 / \mathrm{m}^{2}$ day from February to July, and 0.1 to $2.1 \mathrm{l} / \mathrm{m}^{2}$ day from August to January. In other places around the world, fog interception has been quantified as well. In Mauna Loa in Hawaii at 2530 and $1580 \mathrm{~m}$ a.s.1., fog interception ranges between 1.9 and $2.11 / \mathrm{m}^{2}$ day (Juvik and Ekern, 1978), in Sierra Madre, Mexico, values between 0.4 and $1.61 / \mathrm{m}^{2}$ day were registered at elevations of 1330 to 1900 m a.s.l. (Vogelmann, 1973); whereas at Venezuela (in El Zumbador, Cerro Copey and Cerro Santa Ana at 3100, 987 and $815 \mathrm{~m}$ a.s.l., respectively) and Colombia (in Maguira at $865 \mathrm{~m}$ a.s.1.), fog interception ranges between 0.2 and $2.2 \mathrm{l} / \mathrm{m}^{2}$ day (Cavelier and Goldstein, 1989). The values found in this study show that fog collection in Galapagos is above the average, and it is placed among the sites with higher fog collection potential (Fig. 5).

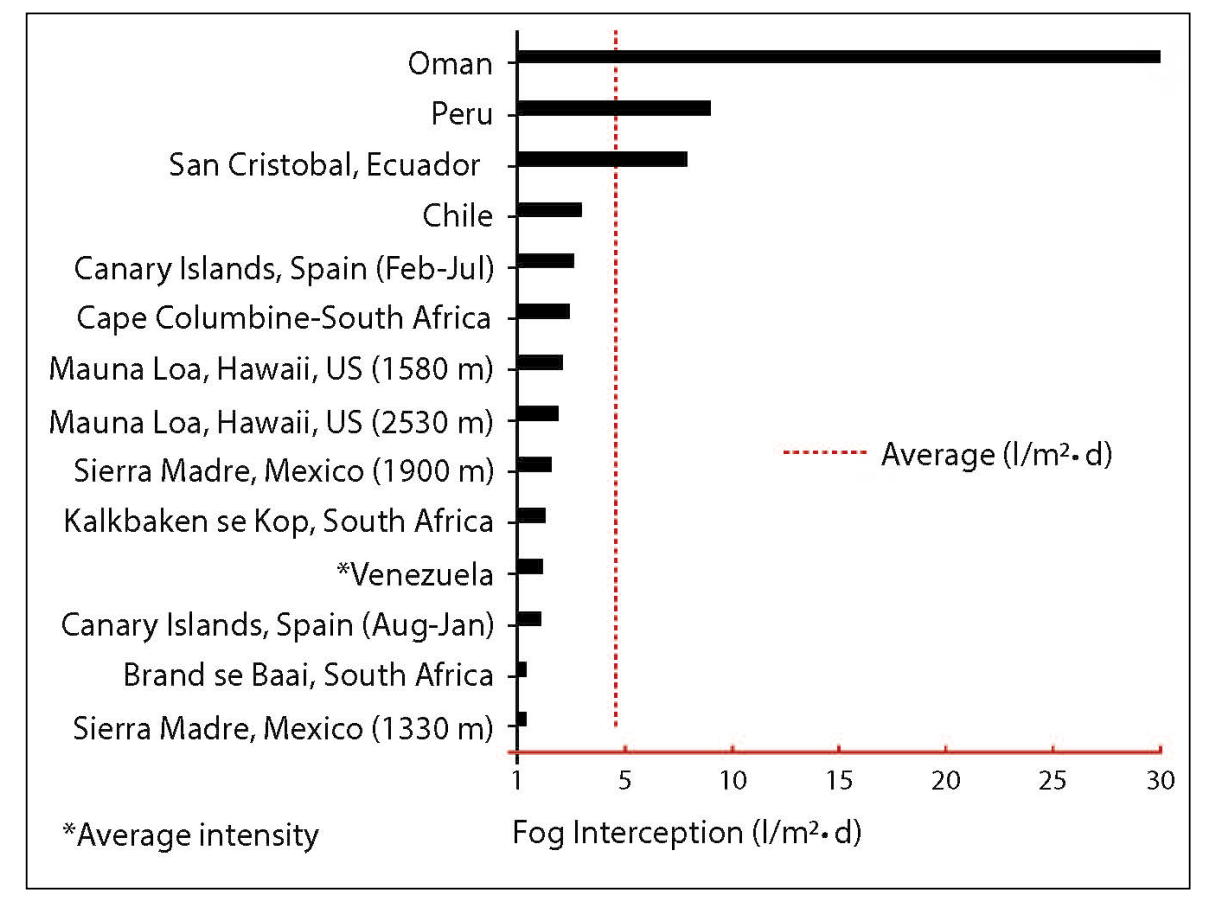

Figure 5. Fog interception in several locations around the globe. 
Considering fog harvesting potential in Galapagos and a 200 litters per capita per day suggested water demand in the rural zone, if 5 collectors are installed ( $24 \mathrm{~m}^{2} 50$-SFC devices), $100 \%$ of water supply would be covered for a farm of 4 habitants, which is the regular family size in this area. Water deficit for irrigation purposes in San Cristobal is estimated at 9.1 and $10.4 \mathrm{l} \mathrm{s}^{-1}$, in the average and dry years, respectively; with the implementation of 67 collectors (48 $\mathrm{m}^{2}$ 50-SFC devices) in an average year, and 76 collectors in a dry year, $25 \%$ of water deficit for agriculture could be covered. This is a fair alternative of water supply given that the availability of space is not a limitation in the rural zone of the island, the cost is relatively cheap and the system configuration could be adjusted to the needs of each farm, as well as the size of storage tanks. It should be noticed that water demand could increase considerably with the population growth and tourism demand, even though, the local government has strict policies, in which immigration is restricted, and product activities are limited for conservation purposes. Further studies are necessary to study the impact of these devices in the landscape and if the massive use of these devices could affect negatively water availability on the highlands.

\section{Conclusions}

We studied the fog collection potential in San Cristobal Island with three different fog gauges. The 50\% shade coefficient standard fog collector is the most efficient gauge collecting in average $7 \mathrm{~mm} \mathrm{day}^{-1}$ of fog and $7.91 / \mathrm{m}^{2}$ day of water. Even though fog is present only during seven months along the year, based on the results, the use of these devices can contribute to the water supply and to enhance the productive activities in Galapagos. Each farm could install a fog collector system according to its needs, especially when these farms have no access to the water supply network. In addition, it is possible to apply this alternative in other inhabited islands of the archipelago, such as Santa Cruz and Floreana, where water scarcity is even worse due to the absence of permanent superficial water sources.

\section{Acknowledgements}

This study has been conducted in the frame of the project Galapagos Islands Integrated Water Studies. The GIIWS team would like to thank Galapagos Conservancy, Universidad Politécnica Salesiana and the ENS - UMR.8538 Laboratoire de Géologie for funding this research We also want to thank our local partners in the Galapagos: Charles Darwin Research Station, Galapagos National Park (permit: PC-27-16), and private land owners. We thank the valuable comments made by the Editor and the reviewers.

\section{References}

Abdul-Wahab, S.A., Al-Damkhi, A.M., Al-Hinai, H., Al-Najar, K.A., and Al-Kalbani, M.S. 2010. Total fog and rainwater collection in the Dhofar region of the Sultanate of Oman during the monsoon season. Water International, 35(1), 100-109. https://doi. org/10.1080/02508060903502984. 
Alpert, L. 1946. Notes on the weather and climate of Seymour Island, Galapagos Archipelago. Bulletin of the American Meteorological Society 27, 200-209.

Batisha, A. F. 2015. Feasibility and sustainability of fog harvesting. Sustainability of Water Quality and Ecology, 6, 1-10. https://doi.org/10.1016/j.swaqe.2015.01.002.

Brauman,K.A.,Freyberg, D.L., Daily, G.C.2010. Forest structure influences on rainfall partitioning and cloud interception: A comparison of native forest sites in Kona, Hawai'i. Agricultural and Forest Meteorology 150 (2), 265-275. https://doi.org/10.1016/j.agrformet.2009.11.011.

Cavelier, J., Goldstein, G. 1989. Mist and fog interception in elfin cloud forests in Colombia and Venezuela. Journal of Tropical Ecology 5 (3), 309-322. https://doi.org/10.1017/ S0266467400003709.

Cereceda, P., Hernández, P., Leiva, J., Rivera, J.D. 2014. Agua de Niebla. Pontificia Universidad Católica, Santiago.

Cereceda, P., Schemenauer, R.S., Suit, M. 1992. An alternative water supply for Chilean coastal desert villages. International Journal of Water Resources Development 8 (1), 53-59. https:// doi.org/10.1080/07900629208722533.

Chang Jiang Institute of Survey Planning, Design and Research (CISPDR) 2015. La Planificación de los Recursos Hídricos de las Islas Galápagos. Ecuador.

Domínguez, C. 2016. Integrated hydrogeological study of San Cristobal Island (Galápagos) (PhD Thesis). Université Pierre et Marie Curie, París.

Domínguez, C.G., García Vera, M.F., Chaumont, C., Tournebize, J., Villacís, M., d’Ozouville, N., Violette, S. 2017. Quantification of cloud water interception in the canopy vegetation from fog gauge measurements. Hydrological Processes 31 (18), 3191-3205. https://doi. org/10.1002/hyp.11228.

Estrela, M.J., Valiente, J.A., Corell, D., Millán, M.M. 2008. Fog collection in the western Mediterranean basin (Valencia region, Spain). Atmospheric Research 87 (3-4), 324-337. https://doi.org/10.1016/j.atmosres.2007.11.013.

Eugster, W., Burkard, R., Holwerda, F., Scatena, F.N., Bruijnzeel, L.S. 2006. Characteristics of fog and fogwater fluxes in a Puerto Rican elfin cloud forest. Agricultural and Forest Meteorology, 139 (3), 288-306. https://doi.org/10.1016/j.agrformet.2006.07.008.

Fessehaye, M., Abdul-Wahab, S.A., Savage, M.J., Kohler, T., Gherezghiher, T., Hurni, H. 2014. Fog-water collection for community use. Renewable and Sustainable Energy Reviews 29, 52-62. https://doi.org/10.1016/j.rser.2013.08.063.

Food and Agriculture Organization (FAO) 2006. Evapotranspiración del cultivo. Guías para la determinación de los requerimientos de agua de los cultivos. Roma.

Frumau, K.F., Burkard, R., Schmid, S., Bruijnzeel, L.A., Tobón, C., Calvo-Alvarado, J.C. 2011. A comparison of the performance of three types of passive fog gauges under conditions of wind-driven fog and precipitation. Hydrological Processes 25 (3), 374-383. https://doi. org/10.1002/hyp.7884.

Giambelluca, T.W., Nullet, D. 1991. Influence of the trade-wind inversion on the climate of a leeward mountain slope in Hawaii. Climate Research, 1 (3), 207-216.https://doi.org/10.3354/ cr001207.

Gunn, R., Kinzer, G.D. 1949. The terminal velocity of fall for water droplets in stagnant air. Journal of Meteorology 6 (4), 243-248. https://doi.org/10.1175/1520-0469(1949)006<0243:TTVOF $\mathrm{F}>2.0 . \mathrm{CO} ; 2$.

Herwitz, S.R., Slye, R.E. 1995. Three-dimensional modeling of canopy tree interception of wind-driven rainfall. Journal of Hydrology, 168 (1), 205-226. https://doi.org/10.1016/00221694(94)02643-P.

Holwerda, F., Burkard, R., Eugster, W., Scatena, F.N., Meesters, A., Bruijnzeel, L.A. 2006. Estimating fog deposition at a Puerto Rican elfin cloud forest site: comparison of the water 
budget and eddy covariance methods. Hydrological Processes 20 (13), 2669-2692. https:// doi.org/10.1002/hyp.6065.

Instituto Nacional de Estadísticas y Censos (INEC) 2010. Available at: http://www .ecuadorencifras. gob.ec/sistema-integrado-de-consultas-redatam/ (last access: 11/06/2019).

Juvik, J.O., Ekern, P.C. 1978. A climatology of mountain fog on Mauna Loa, Hawaii Island. Available from the National Technical Information Service, Springfield VA 22161 as PB 80-118805. Price Codes: A 04 in Paper Copy, A 01 in Microfiche. Technical Report, 118.

Klemm, O., Schemenauer, R.S., Lummerich, A., Cereceda, P., Marzol, V., Corell, D., Fessehaye, G.M. 2012. Fog as a Fresh-Water Resource: Overview and Perspectives. Ambio 41 (3), 221234. https://doi.org/10.1007/s13280-012-0247-8.

Laws, J.O., Parsons, D.A. 1943. The relation of raindrop-size to intensity. Eos, Transactions of the American Geophysical Union 24 (2), 452-460.

Olivier, J. 2002. Fog-water harvesting along the West Coast of South Africa: A feasibility study. Water SA, 28 (4), 349-360. https://doi.org/10.4314/wsa.v28i4.4908.

Pryet, A., Dominguez, C., Tomai, P. F., Chaumont, C., d'Ozouville, N., Villacís, M., Violette, S. 2012. Quantification of cloud water interception along the windward slope of Santa Cruz Island, Galapagos (Ecuador). Agricultural and Forest Meteorology 161, 94-106. https://doi. org/10.1016/j.agrformet.2012.03.018.

Regalado, C.M., Ritter, A. 2017. The performance of three fog gauges under field conditions and its relationship with meteorological variables in an exposed site in Tenerife (Canary Islands). Agricultural and Forest Meteorology 233, 80-91. https://doi.org/10.1016/j. agrformet.2016.11.009

Ritter, A., Regalado, C. M., Aschan, G. 2008. Fog Water Collection in a Subtropical Elfin Laurel Forest of the Garajonay National Park (Canary Islands): A Combined Approach Using Artificial Fog Catchers and a Physically Based Impaction Model. Journal of Hydrometeorology 9 (5), 920-935. https://doi.org/10.1175/2008JHM992.1.

Ritter, A., Regalado, C.M., Guerra, J.C. 2015. Quantification of Fog Water Collection in Three Locations of Tenerife (Canary Islands). Water 7 (7), 3306-3319. https://doi.org/10.3390/w7073306.

Rivera, J.D. 2011. Aerodynamic collection efficiency of fog water collectors. Atmospheric Research 102 (3), 335-342. https://doi.org/10.1016/j.atmosres.2011.08.005.

Sachs, J.P., Sachse, D., Smittenberg, R.H., Zhang, Z., Battisti, D.S., Golubic, S. 2009. Southward movement of the Pacific intertropical convergence zone AD[thinsp]1400-1850. Nature Geoscience 2 (7), 519-525. https://doi.org/10.1038/ngeo554.

Schemenauer, R.S., Cereceda, P. 1994a. A Proposed Standard Fog Collector for Use in HighElevation Regions. Journal of Applied Meteorology 33 (11), 1313-1322. https://doi. org/10.1175/1520-0450(1994)033<1313:APSFCF>2.0.CO;2.

Schemenauer, R.S., Cereceda, P. 1994b. Fog collection's role in water planning for developing countries. Natural Resources Forum 18, 91-100. Wiley Online Library.

Schemenauer, R.S., Joe, P.I. 1989. The collection efficiency of a massive fog collector. Atmospheric Research 24 (1), 53-69. https://doi.org/10.1016/0169-8095(89)90036-7.

Sicart, J.E., Hock, R., Six, D. 2008. Glacier melt, air temperature, and energy balance in different climates: The Bolivian Tropics, the French Alps, and northern Sweden. Journal of Geophysical Research: Atmospheres 113 (D24). https://doi.org/10.1029/2008JD010406.

Trueman, M., d'Ozouville, N. 2010. Characterizing the Galapagos terrestrial climate in the face of global climate change. Galapagos Research 67, 26-37. http://aquaticcommons.org/id/ eprint/21473.

Villegas, J.C., Tobón, C., Breshears, D.D. 2008. Fog interception by non-vascular epiphytes in tropical montane cloud forests: dependencies on gauge type and meteorological conditions. Hydrological Processes, 22 (14), 2484-2492. https://doi.org/10.1002/hyp.6844. 
Violette, S., d'Ozouville, N.,Pryet, A., Deffontaines, B.,Fortin, J., Adelinet, M. 2014. Hydrogeology of the Galapagos Archipelago: an integrated and comparative approach between islands. In: K.S. Harpp, E., Mittelstaedt, N. d'Ozouville, D.W. Graham, The Galapagos: A Natural Laboratory for the Earth Sciences. AGU Advancing Earth and Space Science, 204, 167. https://doi.org/10.1002/97811188552538.ch9.

Vogelmann, H.W. 1973. Fog Precipitation in the Cloud Forests of Eastern Mexico. BioScience 23 (2), 96-100. https://doi.org/10.2307/1296569. 